\title{
Gene variants of adhesion molecules predispose to MS: A case-control study
}

Efthimios Dardiotis, MD, Elena Panayiotou, PhD, Vasileios Siokas, MD, Athina-Maria Aloizou, MS, Kyproula Christodoulou, PhD, Andreas Hadjisavvas, PhD, Marios Pantzaris, MD, Nikolaos Grigoriadis, MD, Georgios M. Hadjigeorgiou, MD, and Theodoros Kyriakides, MD

Neurol Genet 2019;5:e304. doi:10.1212/NXG.0000000000000304

\section{Abstract}

\section{Objective}

To examine the effect of variants in genes encoding molecules that are implicated in leukocyte trafficking into the CNS on the development of MS.

\section{Methods}

A total of 389 Greek MS cases and 336 controls were recruited by 3 MS centers in Cyprus and Greece. In total, 147 tagging single nucleotide polymorphisms across 9 genes encoding for P-selectin (SELP), integrins (ITGA4, ITGB1, and ITGB7), adhesion molecules (ICAM1, $V C A M 1$, and MADCAM1), fibronectin 1 (FN1), and osteopontin (SPP1) were genotyped. The clinical end point of the study was diagnosis of MS according to the 2005 revised McDonald criteria. Permutation analysis was used for adjusting for multiple comparisons.

\section{Results}

Overall, 21 variants across SELP, ITGA4, ITGB1, ICAM1, VCAM1, MADCAM1, FN1, and SSP1 genes were each associated with MS ( $\left.p_{\text {perm }}<0.05\right)$. The most significant were rs3917779 and rs2076074 (SELP), rs6721763 (ITGA4), and rs1250258 (FN1), all with a permutation $p$ value of less than $1 \mathrm{e}-004$.

\section{Conclusions}

The current study provides preliminary evidence that variants across genes encoding adhesion molecules, responsible for lymphocyte adhesion and trafficking within the CNS, are implicated in the risk of developing MS.

\author{
Correspondence \\ Dr. Kyriakides \\ theodore@cing.ac.cy
}




\section{Glossary}

BBB = blood-brain barrier; CGAS = candidate gene association study; DMT = disease-modifying therapy; EDSS = Kurtzke Expanded Disability Status Scale; GWAS = genome-wide association study; LD = linkage disequilibrium; MAF = minor allele frequency; MSSS = Multiple Sclerosis Severity Score; OR = odds ratio; SELP = P-selectin; SNP = single nucleotide polymorphism.

MS is a common complex immune-mediated disease of the CNS. ${ }^{1}$ Inflammation, demyelination, axonal loss, and neurodegeneration appear during the course of MS. ${ }^{2}$ Although the proximal pathogenic mechanisms that lead to MS development still remain largely unclear, there is evidence that hints toward an interplay between genetic background, environment factors, and epigenetic modifications conferring susceptibility to MS. ${ }^{3}$

A few genetic variants that confer susceptibility to MS have been identified through candidate gene association studies (CGASs), linkage and genome-wide linkage analyses, and genome-wide association studies (GWASs). ${ }^{4}$ Over 110 genetic risk factors of MS have been identified. ${ }^{5}$ However, most studies have yielded inconsistent results, with limited replication of the reported associations. ${ }^{6}$

Several molecules have been implicated in the adhesion and diapedesis of leukocytes via the blood-brain barrier (BBB), as well as their migration from the extracellular matrix to the target tissue. ${ }^{7}$ The protective effect of an antibody against $a 4$ integrin (natalizumab) in MS supports the hypothesis that the ingress of leukocytes into the brain parenchyma is a crucial step. ${ }^{8}$ We have previously reported that variants of genes coding for proteins implicated in leukocyte trafficking across the BBB influence the severity of MS (namely rs6721763 [ITGA4] and rs6532040 [SPP1]) and have an effect on disease onset (rs1250249 [FN1]). ${ }^{9}$ Therefore, we also hypothesize that variants of these molecules may also predispose to MS development.

The present study examines tagging single nucleotide polymorphisms (SNPs) in P-selectin (SELP), integrins $\alpha 4, \beta 1$, and $\beta 7$, adhesion molecules ICAM1, VCAM1, and MADCAM1, fibronectin 1 , and osteopontin genes for possible association with MS risk.

\section{Methods}

\section{Study population}

Our cohort consisted of Greek patients with MS and controls from 3 MS centers: the Cyprus Institute of Neurology and Genetics in Cyprus, the University Hospital of Larissa, Greece, and the AHEPA Hospital of Aristotle University in Thessaloniki, Greece, that have been previously described in detail. ${ }^{9}$ In short, a total of 389 MS cases and 336 controls have participated in the study. The diagnosis of MS was assessed according to the 2005 revised McDonald criteria. ${ }^{10}$ All participants were aged $\geq 18$ years and had a disease duration of $\geq 5$ years. We did not include primary progressive MS cases.
The same criteria for collection of clinical and demographic data were applied at each center. Participants' sex, current age, age at disease onset (defined as age of the first neurologic symptom suggestive of MS), use of disease-modifying therapies (DMTs), and duration of treatment were recorded. Using the Kurtzke Expanded Disability Status Scale (EDSS), ${ }^{11}$ the disability status was assessed in the absence of relapse for at least 6 months. The time from the first symptom suggestive of MS to the last EDSS assessment was considered as the disease duration (in years) for each patient. The progression index was applied to express the rate of disease progression. By means of the Multiple Sclerosis Severity Score (MSSS), disease severity was estimated. ${ }^{12}$

The unrelated healthy control group was matched for age and sex and consisted of healthy volunteers from the same ethnic regions.

\section{Standard protocol approvals, registrations, and patient consents}

The study received approval from the respective institutional ethical standards committee on human experimentation for any experiments using human patients. Written informed consent was obtained from all patients (or guardians of patients) participating in the study (consent for research).

\section{DNA isolation, selection of tagging SNPs, and genotyping procedure}

With the puregene DNA purification kit (Qiagen, Valencia, CA), we isolated DNA from peripheral blood samples. Variants across the following genes were genotyped: (1) SELP, (2) ITGA4, (3) ITGB1, (4) ITGB, (5) ICAM1, (6) VCAM1, (7) MADCAM1, (8) FN1, and (9) SPP1.

Tagging SNPs were identified on the basis of linkage disequilibrium (LD) blocks according to the HapMap project. More precisely, the selection was based on the CEU (Utah residents with Northern and Western European ancestry from the CEPH [Centre d'Etude du Polymorphisme Humain collection]) population at the HapMap Release 27 database (Phase II + III, Feb09, on National Center for Biotechnology Information B36 assembly, dbSNP b126). Pairwise $r^{2}$ values $\geq 0.8$ and minor allele frequency (MAF) $>0.05$ were the applied criteria. Thirty-two tagging SNPs in the SELP gene, 36 in the ITGA4 gene, 16 in ITGB1, 3 in ITGB7, 5 in ICAM1, 15 in VCAM1, 3 in MADCAM1, 38 in FN1, and 8 in SPP1, which add up to 156 SNPs, were retrieved. Studied tagging SNPs' characteristics and information regarding their genes are available in table e-1 (links.lww.com/NXG/A137). 
TaqMan 5' -nuclease assays were used to genotype SNPs by acquiring specific assays for each SNP and then performing allelic discrimination assays on the ABI 7900HT Real-Time System (Applied Biosystems, Foster City, CA). Nine SNPs failed to be genotyped, whereas the genotypic rates were above $96 \%$.

\section{Statistical analysis}

The exact test, with a $p$ value of $\leq 0.05$, was considered as indicative for deviation from the Hardy-Weinberg equilibrium in the control group for each SNP. ${ }^{13}$ Haploview software version 4.2 (broadinstitute.org/scientific-community/science/ programs/medical-and-population-genetics/haploview/haploview) was applied in each gene in order for pairwise $\mathrm{D}^{\prime}$ and $r^{2}$ between variants and LD blocks to be calculated. ${ }^{14,15}$ The power of the sample was calculated using CaTS software (csg. sph.umich.edu/abecasis/cats/gas_power_calculator/index. html). ${ }^{16}$ Quality control with a threshold lower than $0.05 \%$ was performed by calculating MAFs. Allelic association regression analysis was performed using PLINK 1.07 software (zzz.bwh. harvard.edu/plink/). ${ }^{17} p$ values were corrected for multiple testing by means of permutation analysis. A total of 10,000 permutations were performed to correct the $p$ value. Value less than 0.05 was set as the statistically significant threshold.

\section{Data availability statement}

Anonymized data will be shared by request from any qualified investigator.

Table 1 Demographic and clinical characteristics of study participants

\begin{tabular}{|c|c|c|c|c|c|c|c|}
\hline & $\begin{array}{l}\text { Total } \\
\text { patients }\end{array}$ & Controls & $\begin{array}{l}\text { Cyprus } \\
\text { patients }\end{array}$ & $\begin{array}{l}\text { Cyprus } \\
\text { controls }\end{array}$ & $\begin{array}{l}\text { Larissa } \\
\text { patients }\end{array}$ & $\begin{array}{l}\text { Larissa } \\
\text { controls }\end{array}$ & $\begin{array}{l}\text { Thessaloniki } \\
\text { patients }\end{array}$ \\
\hline $\mathbf{n}$ & 389 & 336 & 104 & 127 & 206 & 209 & 79 \\
\hline Female, n (\%) & $251(64.5)$ & $234(69.6)$ & $74(71.2)$ & $88(69.3)$ & $126(61.2)$ & $146(69.9)$ & $51(64.6)$ \\
\hline Male, $n(\%)$ & $138(35.5)$ & $102(30.4)$ & $30(28.8)$ & 39 (30.7) & $80(38.8)$ & $63(30.1)$ & $28(35.4)$ \\
\hline Female:male ratio & $1.8: 1$ & $2.3: 1$ & $2.5: 1$ & 2.3:1 & $1.6: 1$ & 2.3:1 & $1.8: 1$ \\
\hline $\begin{array}{l}\text { Age at disease onset, } \\
\text { mean (range) }\end{array}$ & $30.4(18-63)$ & & $35.3(18-58)$ & & $29.0(18-63)$ & & $27.9(18-50)$ \\
\hline $\begin{array}{l}\text { Age at the time of analysis, } \\
\text { mean (range) }\end{array}$ & $43.3(23-74)$ & $36.3(23-78)$ & $43.8(25-66)$ & $47.4(20-78)$ & $43.0(23-74)$ & $29.6(23-58)$ & $41.9(23-63)$ \\
\hline Disease duration $(y)$, mean & 12.9 & & 12.44 & & 12.77 & & 13.90 \\
\hline Median (range) & $11(5-52)$ & & $11(5-35)$ & & $10(5-52)$ & & $12(5-38)$ \\
\hline $\begin{array}{l}\text { Time from } 1 \text { st to } 2 \text { nd } \\
\text { relapse }(\mathrm{mo}) \text {, mean (SD) }\end{array}$ & $40.1(52.3)$ & & $44.8(54.1)$ & & $36.1(51.8)$ & & $44.3(50.6)$ \\
\hline Monosymptomatic onset, $\mathrm{n}(\%)$ & $268(74.9)$ & & $94(90.4)$ & & $132(69.8)$ & & $42(64.6)$ \\
\hline DMT, n (\%) & $271(69.7)$ & & $71(68.3)$ & & $131(63.6)$ & & $69(87.3)$ \\
\hline DMT time (mo) (SD) & $72.1(44.2)$ & & $73.6(49.6)$ & & $70.4(43.3)$ & & $73.9(40.2)$ \\
\hline \multicolumn{8}{|l|}{ EDSS, $n$ (\%) } \\
\hline$<3$ & $188(47.8)$ & & $69(66.3)$ & & $84(40.8)$ & & $33(41.8)$ \\
\hline 3 to $<6$ & $114(29.3)$ & & $27(26.0)$ & & $54(26.2)$ & & $33(41.8)$ \\
\hline $6-6.5$ & $40(10.3)$ & & $6(5.8)$ & & $25(21.1)$ & & $9(11.4)$ \\
\hline$\geq 7$ & $35(9.0)$ & & $2(1.9)$ & & $31(15.0)$ & & $2(2.5)$ \\
\hline Mean (SD) & $3.40(2.16)$ & & $2.44(1.54)$ & & $3.83(2.46)$ & & $3.61(1.59)$ \\
\hline Progression index, mean (SD) & $0.31(0.24)$ & & $0.22(0.15)$ & & $0.34(0.24)$ & & $0.35(0.31)$ \\
\hline \multicolumn{8}{|l|}{ MSSS } \\
\hline Median & 4.00 & & 3.00 & & 5.00 & & 5.00 \\
\hline Mean (SD) & $4.39(2.61)$ & & $3.18(1.98)$ & & $4.92(2.89)$ & & $4.71(2.00)$ \\
\hline Benign MS (MSSS = [1-2]), n (\%) & $109(28.0)$ & & $49(47.1)$ & & $51(24.8)$ & & $9(11.4)$ \\
\hline Severe MS (MSSS = [7-10]), n (\%) & $86(22.1)$ & & $9(8.7)$ & & $61(29.6)$ & & $16(20.3)$ \\
\hline
\end{tabular}

Abbreviations: DMT = disease-modifying treatment; EDSS = Kurtzke Expanded Disability Status Scale; MSSS = Multiple Sclerosis Severity Score. 


\section{Results}

Detailed characteristics of the recruited cohort have been previously extensively described..$^{9}$ In brief, 251 patients (64.5\%) were women. Two hundred seventy-one patients (69.7\%) were under DMT. Two hundred thirty-four healthy controls $(69.6 \%)$ were women. The mean age of the control group was 36.3 years. Detailed clinical and demographic data of controls and patients are presented in table 1.

According to the power analysis, our study had a power of $80.0 \%$ to detect an association of a variant with a genetic relative risk of 1.729, assuming the multiplicative model, MAF equal to $5 \%$ (the lowest in MS cases for the rs3917714), type I error level of 0.05 , in a sample of 336 controls and 389 MS cases.

The distribution of the variants that were analyzed in our cohort, in distinct $\mathrm{LD}$ blocks across genes, and the pairwise $\mathrm{D}^{\prime}$ and $r^{2}$ values between them are demonstrated in figure e-1 (links.lww.com/NXG/A136).
According to allelic association regression analysis, significant associations (with $p_{\text {perm }}<0.05$ ) were found for 21 SNPs in total. Namely, 8 SELP polymorphisms (rs3917779, rs3917768, rs2142760, rs3917744, rs2076074, rs3917740, rs3917727, and rs3917709), 7 ITGA4 polymorphisms (rs12988934, rs11694175, rs17224277, rs155103, rs17225354, rs11689738, and rs6721763), 1 ITGB1 polymorphism (rs10763902), 1 ICAM1 polymorphism (rs281437), 1 VCAM1 polymorphism (rs3176878), 1 MADCAM1 polymorphism (rs12982646), 1 FN1 polymorphism (rs1250258), and 1 SSP1 polymorphism (rs6532040) were found to reach a statistical significant level. The most statistically significant $p_{\text {perm }}$ values were reached from rs3917779 and rs2076074 (SELP), rs6721763 (ITGA4), and rs1250258 (FN1), with a permutation $p$ value equal to $9.999 \mathrm{e}-$ 005. The odds ratios [ORs], 95 CIs, and the permutation $p$ values after correction for multiple testing for statistically significant variants (stressed according to the permutation $p$ value) are presented in table 2 . The ORs, 95 CIs, $p$ values, and the permutation $p$ values after correction for multiple testing for each variant are presented in table e-2 (links.lww.com/NXG/A137).

Table 2 Rs number, gene, OR, 95\% Cl, and permutation $p$ value for the statistical significant variants resulted from allelic association analysis association with MS risk (MS cases vs healthy controls)

\begin{tabular}{|c|c|c|c|}
\hline rs number & Gene & OR $(95 \% \mathrm{Cl})$ & Permutation $p$ value \\
\hline rs3917779 & SELP & $3.08(1.943-4.883)$ & $9.999 \mathrm{e}-005$ \\
\hline rs2076074 & SELP & 2.07 (1.594-2.689) & $9.999 \mathrm{e}-005$ \\
\hline rs6721763 & ITGA4 & $0.5542(0.448-0.6855)$ & $9.999 \mathrm{e}-005$ \\
\hline rs1250258 & FN1 & $0.6427(0.5155-0.8013)$ & $9.999 \mathrm{e}-005$ \\
\hline rs12982646 & MADCAM1 & $1.661(1.248-2.212)$ & 0.0007999 \\
\hline rs6532040 & SPP1 & $1.551(1.253-1.92)$ & 0.0003 \\
\hline rs17224277 & ITGA4 & $0.5479(0.3718-0.8074)$ & 0.0009999 \\
\hline rs3176878 & VCAM1 & $1.667(1.263-2.2)$ & 0.0009999 \\
\hline rs3917709 & SELP & $1.831(1.255-2.673)$ & 0.0018 \\
\hline rs17225354 & ITGA4 & $0.7332(0.5918-0.9084)$ & 0.0036 \\
\hline rs10763902 & ITGB1 & $1.418(1.119-1.796)$ & 0.0048 \\
\hline rs11689738 & ITGA4 & $1.363(1.097-1.694)$ & 0.005199 \\
\hline rs11694175 & ITGA4 & $1.33(1.074-1.646)$ & 0.005299 \\
\hline rs3917768 & SELP & $1.357(1.092-1.685)$ & 0.005399 \\
\hline rs155103 & ITGA4 & $0.7048(0.5454-0.9108)$ & 0.007199 \\
\hline rs3917740 & SELP & $0.6807(0.5127-0.9038)$ & 0.008099 \\
\hline rs2142760 & SELP & $1.32(1.059-1.647)$ & 0.0148 \\
\hline rs12988934 & ITGA4 & $1.74(1.11-2.728)$ & 0.016 \\
\hline rs3917727 & SELP & $0.7883(0.6376-0.9745)$ & 0.0201 \\
\hline rs281437 & ICAM1 & $0.7691(0.6234-0.9488)$ & 0.0405 \\
\hline rs3917744 & SELP & $0.8048(0.6478-0.9999)$ & 0.0485 \\
\hline
\end{tabular}

Abbreviations: $\mathrm{Cl}=$ cluster interval; $\mathrm{OR}=$ odds ratio. 


\section{Discussion}

The present research aimed at investigating a possible association between predisposition to MS and variants of genes that are implicated in leukocyte trafficking into the CNS. The 147 tagging SNPs across 9 genes were selected with the LD block method and further analyzed. Our analysis revealed associations between 21 tagging SNPs across SELP, ITGA4, ITGB1, ICAM1, VCAM1, MADCAM1, FN1, and SSP1 and MS. This result needs further replication in ethnically different and even larger groups.

Recently, a renewed effort to identify genetic variants conferring susceptibility to MS has been made. A few variants have emerged through CGASs and GWASs. ${ }^{5,6,18-20}$ However, CGASs and GWASs have yielded inconsistent findings, with limited replication of genetic variants. ${ }^{6}$ Previous CGASs have focused on pathways related to autoimmunity, immune function, myelin structure, and the human leukocyte antigen, which also yielded inconsistent results. ${ }^{21,22}$ It is possible that the complexity of MS pathophysiology, ${ }^{5}$ the interplay between environmental and genetic risk factors, epistasis between loci, and the lack of systematic exploration of rare variations in MS susceptibility may be responsible, to some degree, for the low reproducibility of MS loci in different studies. ${ }^{6,18}$

The SELP protein is stored in the alpha-granules of platelets and Weibel-Palade bodies of endothelial cells. ${ }^{23}$ During platelet activation and degranulation, SELP is redistributed to the plasma membrane and mediates the interaction between leukocytes and activated endothelial cells or platelets. ${ }^{23}$ Eight SELP polymorphisms (rs3917779, rs3917768, rs2142760, rs3917744, rs2076074, rs3917740, rs3917727, and rs3917709) have reached the statistically significant threshold in our study. The rs3917779, rs3917768, and rs 2142760 are in block 2 according to LD values. This region of the SELP gene, that spans approximately $7.8 \mathrm{~kb}$ between the 2 extremes (rs3917786 and rs2142760, with a value of $\mathrm{D}^{\prime}$ equal to 0.986 ), appears to represent an important part across the SELP gene and may affect the expression of the gene. Every single SNP within this region may confer an additional risk to the development of MS.

The ITGA4 gene encodes the $\alpha 4$ subunit of the $\alpha 4 \beta 1$ integrin. This integrin is involved in the adhesion and migration procedures of leukocytes through the BBB. ${ }^{7}$ ITGA4 is already an approved treatment target in clinical practice in relapsingremitting MS, with the monoclonal antibody natalizumab. ${ }^{24} \mathrm{~A}$ few variants (rs1143676, rs1449263, and rs6721763) in ITGA4 have been linked to MS risk. ${ }^{9,25-27}$ Of interest, the intronic rs6721763 (intron 17-18), which has been found to be associated with MS risk, has also been associated with disease severity, as evaluated with the MSSS. ${ }^{9}$

Osteopontin consists a secreted matrix protein, which is involved in processes regarding activation, proliferation, and migration of $\mathrm{T}$ cells. ${ }^{28}$ The intronic $\mathrm{rs} 6532040$ has been found to confer susceptibility to MS, based on our results. The rs6532040 of SPP1 has been previously reported to be a genetic modifier of MS course. ${ }^{9}$

Fibronectin 1 is an extracellular matrix glycoprotein. Its main function includes cytoskeleton organization, cell adhesion, and migration. ${ }^{29}$ Previously, the FN1 rs1250249 has been found to exert a dose-dependent effect on MS onset. ${ }^{9}$ However, this polymorphism does not seem to be associated with the risk of developing MS in our study. In contrast, the FN1 rs $1250258\left(p_{\text {perm }}=9.999 \mathrm{e}-005\right)$ is strongly associated with MS risk in our cohort. The rs 1250258 is $12.9 \mathrm{~kb}$ away from the rs1250249, and in low $\mathrm{LD}\left(\mathrm{D}^{\prime}=0.048\right)$, suggesting that additional loci across FN1 may consist a risk factor for MS.

One polymorphism across each of the ITGB1, ICAM1, $V C A M 1$, and MADCAM1 genes has been associated with MS in our study. Namely, the polymorphisms rs10763902, rs281437, rs3176878, and rs12982646, respectively, have reached $p_{\text {perm }}$ values of $<0.05$. ITGB1, ICAM1, VCAM1, and MADCAM1 are adhesion molecules expressed in the CNS extracellular space. ${ }^{7,90}$ They are mainly implicated in the regulation of the reactivation and migration of lymphocytes to myelinated axons. ${ }^{7,9,30}$

The clinically well-characterized MS group is one of the strengths of our study. Moreover, according to the number of participants, our sample was sufficiently powered to reveal common susceptibility variants of modest effect. In addition, the correction for multiple testing was assessed by means of permutation analysis, an unbiased method.

However, our study has certain limitations. First, it carries all the inherent limitations of studies with a case-control design. Moreover, our concluding remarks would have been more robust if our analysis was accompanied by supportive functional analyses, a validation in an independent sample or an in silico analysis.

In brief, our study implicates variants of genes encoding adhesion molecules, which are mainly involved in lymphocyte ingress and trafficking in the CNS, in the risk of developing MS. The investigation of additional genetic factors that predispose to MS may provide physicians with personalized tools for diagnosis or treatment, particularly in patients with clinically or radiologically isolated syndromes. ${ }^{31}$

\section{Study funding}

The study was supported by the Project YGEIA/BIOS/0609 (BIE/01), which is cofinanced by the European Regional Development Fund and the Republic of Cyprus through the Research Promotion Foundation.

\section{Disclosure}

Efthimios Dardiotis, Elena Panayiotou, Vasileios Siokas, and Athina-Maria Aloizou report no disclosures. Kyproula Christodoulou has received foundation/society research support from the Research Promotion Foundation (Cyprus), Telethon, the 


\begin{tabular}{|c|c|c|c|}
\hline Name & Location & Role & Contribution \\
\hline $\begin{array}{l}\text { Efthimios } \\
\text { Dardiotis, MD }\end{array}$ & $\begin{array}{l}\text { The Cyprus Institute of Neurology and Genetics, } 1683 \\
\text { Nicosia, Cyprus; Department of Neurology, Laboratory of } \\
\text { Neurogenetics, University of Thessaly, University Hospital of } \\
\text { Larissa, Larissa, Greece }\end{array}$ & Author & $\begin{array}{l}\text { Original idea, study design, clinical management and cohort } \\
\text { recruitment, statistical analysis, interpretation of results, } \\
\text { and drafting of the manuscript }\end{array}$ \\
\hline $\begin{array}{l}\text { Elena } \\
\text { Panayiotou, } \\
\text { PhD }\end{array}$ & $\begin{array}{l}\text { The Cyprus Institute of Neurology and Genetics, } 1683 \\
\text { Nicosia, Cyprus; Cyprus School of Molecular Medicine, } \\
\text { Nicosia, Cyprus }\end{array}$ & Author & Experimental work \\
\hline $\begin{array}{l}\text { Vasileios } \\
\text { Siokas, MD }\end{array}$ & $\begin{array}{l}\text { Department of Neurology, Laboratory of Neurogenetics, } \\
\text { University of Thessaly, University Hospital of Larissa, Larissa, } \\
\text { Greece }\end{array}$ & Author & $\begin{array}{l}\text { Statistical analysis, drafting of the manuscript, and clinical } \\
\text { management and cohort recruitment }\end{array}$ \\
\hline $\begin{array}{l}\text { Athina-Maria } \\
\text { Aloizou, MS }\end{array}$ & $\begin{array}{l}\text { Department of Neurology, Laboratory of Neurogenetics, } \\
\text { University of Thessaly, University Hospital of Larissa, Larissa, } \\
\text { Greece }\end{array}$ & Author & $\begin{array}{l}\text { Statistical analysis, drafting of the manuscript, and clinical } \\
\text { management and cohort recruitment }\end{array}$ \\
\hline $\begin{array}{l}\text { Kyproula } \\
\text { Christodoulou, } \\
\text { PhD }\end{array}$ & $\begin{array}{l}\text { The Cyprus Institute of Neurology and Genetics, } 1683 \\
\text { Nicosia, Cyprus; Cyprus School of Molecular Medicine, } \\
\text { Nicosia, Cyprus. }\end{array}$ & Author & Experimental work \\
\hline $\begin{array}{l}\text { Andreas } \\
\text { Hadjisavvas, } \\
\text { PhD }\end{array}$ & $\begin{array}{l}\text { The Cyprus Institute of Neurology and Genetics, } 1683 \\
\text { Nicosia, Cyprus; Cyprus School of Molecular Medicine, } \\
\text { Nicosia, Cyprus. }\end{array}$ & Author & Experimental work \\
\hline $\begin{array}{l}\text { Marios } \\
\text { Pantzaris, MD }\end{array}$ & $\begin{array}{l}\text { The Cyprus Institute of Neurology and Genetics, } 1683 \\
\text { Nicosia, Cyprus }\end{array}$ & Author & Clinical management and cohort recruitment \\
\hline $\begin{array}{l}\text { Nikolaos } \\
\text { Grigoriadis, MD }\end{array}$ & $\begin{array}{l}\text { 2nd Department of Neurology, AHEPA University Hospital, } \\
\text { Aristotle University of Thessaloniki, Thessaloniki, Greece }\end{array}$ & Author & Clinical management and cohort recruitment \\
\hline $\begin{array}{l}\text { Georgios M } \\
\text { Hadjigeorgiou, } \\
\text { MD }\end{array}$ & $\begin{array}{l}\text { Department of Neurology, Medical School, University of } \\
\text { Cyprus, Nicosia, Cyprus }\end{array}$ & Author & Clinical management and cohort recruitment \\
\hline $\begin{array}{l}\text { Theodoros } \\
\text { Kyriakides, MD }\end{array}$ & $\begin{array}{l}\text { The Cyprus Institute of Neurology and Genetics, } 1683 \\
\text { Nicosia, Cyprus; Cyprus School of Molecular Medicine, } \\
\text { Nicosia, Cyprus. }\end{array}$ & Author & $\begin{array}{l}\text { Original idea, study design, clinical management and cohort } \\
\text { recruitment, statistical analysis, interpretation of results, } \\
\text { and drafting of the manuscript. }\end{array}$ \\
\hline
\end{tabular}

Norwegian Financial Mechanism Programme, the Innovative Medicines Initiative, Precisesads, the EU, and Biorise. Andreas Hadjisavvas and Marios Pantzaris report no disclosures. Nikolaos Grigoriadis has served on the scientific advisory boards of Biogen, Bayer, Celgene, Genesis Pharma, Merck Serono, Sanofi, ParadigMS, NavigatingMS, and Helani and has served as a consultant of Biogen, Bayer, Novartis, Celgene, Genesis Pharma, Merck Serono, and Sanofi. Georgios Hadjigeorgiou and Theodoros Kyriakides report no disclosures. Full disclosure form information provided by the authors is available with the full text of this article at Neurology.org/NG.

\section{Publication history}

Received by Neurology: Genetics August 1, 2018. Accepted in final form November 5, 2018.

\section{References}

1. Compston A, Coles A. Multiple sclerosis. Lancet 2008;372:1502-1517.

2. Reich DS, Lucchinetti CF, Calabresi PA. Multiple Sclerosis. N Engl J Med 2018;378: 169-180.

3. Thompson AJ, Baranzini SE, Geurts J, Hemmer B, Ciccarelli O. Multiple sclerosis. Lancet 2018;391:1622-1636.

4. Aggelakis K, Zacharaki F, Dardiotis E, et al. Interleukin-1B and interleukin-1 receptor antagonist gene polymorphisms in Greek multiple sclerosis (MS) patients with boutonset MS. Neurol Sci 2010;31:253-257.

5. Sawcer S, Franklin RJ, Ban M. Multiple sclerosis genetics. Lancet Neurol 2014;13: 700-709.

6. Bashinskaya VV, Kulakova OG, Boyko AN, Favorov AV, Favorova OO. A review of genome-wide association studies for multiple sclerosis: classical and hypothesisdriven approaches. Hum Genet 2015;134:1143-1162.
7. Ley K, Laudanna C, Cybulsky MI, Nourshargh S. Getting to the site of inflammation the leukocyte adhesion cascade updated. Nat Rev Immunol 2007;7:678-689.

8. Polman $\mathrm{CH}, \mathrm{O}$ 'Connor PW, Havrdova E, et al. A randomized, placebo-controlled tria of natalizumab for relapsing multiple sclerosis. N Engl J Med 2006;354:899-910.

9. Dardiotis E, Panayiotou E, Provatas A, et al. Gene variants of adhesion molecules act as modifiers of disease severity in MS. Neurol Neuroimmunol Neuroinflamm 2017;4:e350.

10. Polman $\mathrm{CH}$, Reingold SC, Edan G, et al. Diagnostic criteria for multiple sclerosis: 2005 revisions to the "McDonald Criteria". Ann Neurol 2005;58:840-846.

11. Kurtzke JF. Rating neurologic impairment in multiple sclerosis: an expanded disability status scale (EDSS). Neurology 1983;33:1444-1452.

12. Roxburgh RH, Seaman SR, Masterman T, et al. Multiple Sclerosis Severity Score: using disability and disease duration to rate disease severity. Neurology 2005;64: 1144-1151.

13. Wigginton JE, Cutler DJ, Abecasis GR. A note on exact tests of Hardy-Weinberg equilibrium. Am J Hum Genet 2005;76:887-893.

14. Barrett JC, Fry B, Maller J, Daly MJ. Haploview: analysis and visualization of LD and haplotype maps. Bioinformatics 2005;21:263-265.

15. Gabriel SB, Schaffner SF, Nguyen H, et al. The structure of haplotype blocks in the human genome. Science 2002;296:2225-2229.

16. Skol AD, Scott LJ, Abecasis GR, Boehnke M. Joint analysis is more efficient than replication-based analysis for two-stage genome-wide association studies. Nat Genet 2006;38:209-213.

17. Purcell S, Neale B, Todd-Brown K, et al. PLINK: a tool set for whole-genome association and population-based linkage analyses. Am J Hum Genet 2007;81: 559-575.

18. Baranzini SE, Oksenberg JR. The genetics of multiple sclerosis: from 0 to 200 in 50 years. Trends Genet 2017;33:960-970.

19. Canto E, Oksenberg JR. Multiple sclerosis genetics. Mult Scler 2018;24:75-79.

20. Tizaoui K. Multiple sclerosis genetics: results from meta-analyses of candidate-gene association studies. Cytokine 2018;106:154-164.

21. Ramagopalan SV, Deluca GC, Degenhardt A, Ebers GC. The genetics of clinical outcome in multiple sclerosis. J Neuroimmunol 2008;201-202:183-199.

22. Ramagopalan SV, Deluca GC, Morrison KM, et al. Analysis of 45 candidate genes for disease modifying activity in multiple sclerosis. J Neurol 2008;255:1215-1219.

23. Edwards EE, Thomas SN. P-Selectin and ICAM-1 synergy in mediating THP-1 monocyte adhesion in hemodynamic flow is length dependent. Integr Biol (Camb) 2017;9:313-327. 
24. Rudick RA, Sandrock A. Natalizumab: alpha 4-integrin antagonist selective adhesion molecule inhibitors for MS. Expert Rev Neurother 2004;4:571-580.

25. Durmanova V, Shawkatova I, Javor J, et al. VLA4 Gene polymorphism and susceptibility to multiple sclerosis in Slovaks. Folia Biol (Praha) 2015;61:8-13.

26. O'Doherty C, Roos IM, Antiguedad A, Aransay AM, Hillert J, Vandenbroeck K. ITGA4 polymorphisms and susceptibility to multiple sclerosis. J Neuroimmunol 2007;189:151-157.

27. Andreoli V, Cittadella R, Valentino P, et al. The role of VLA4 polymorphisms in multiple sclerosis: an association study. J Neuroimmunol 2007;189:125-128.
28. Rittling SR, Singh R. Osteopontin in Immune-mediated Diseases. J Dent Res 2015;94: $1638-1645$.

29. Goossens K, Van Soom A, Van Zeveren A, Favoreel H, Peelman LJ. Quantification of fibronectin 1 (FN1) splice variants, including two novel ones, and analysis of integrins as candidate FN1 receptors in bovine preimplantation embryos. BMC Dev Biol 2009;9:1.

30. Baranzini SE, Galwey NW, Wang J, et al. Pathway and network-based analysis of genomewide association studies in multiple sclerosis. Hum Mol Genet 2009;18:2078-2090.

31. Fernández O, Delvecchio M, Edan G, et al. Survey of diagnostic and treatment practices for multiple sclerosis in Europe. Eur J Neurol 2017;24:516-522. 


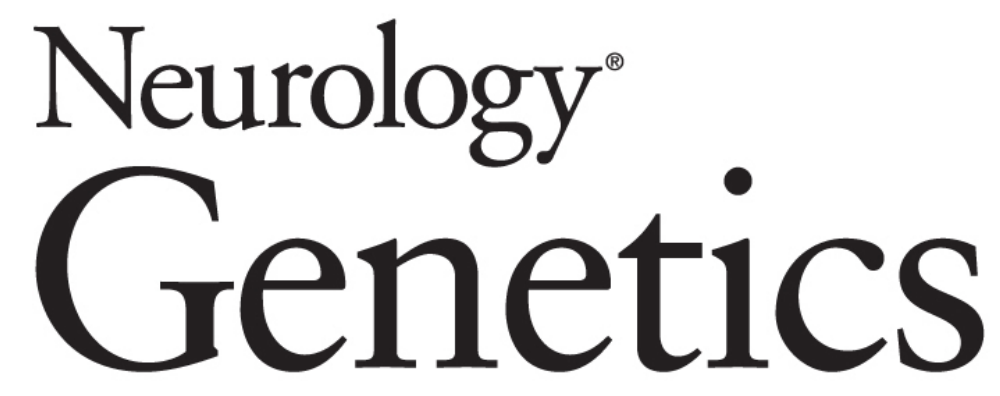

Gene variants of adhesion molecules predispose to MS: A case-control study

Efthimios Dardiotis, Elena Panayiotou, Vasileios Siokas, et al.

Neurol Genet 2019;5;

DOI 10.1212/NXG.0000000000000304

This information is current as of January 16, 2019

\begin{abstract}
Updated Information \& Services

including high resolution figures, can be found at: http://ng.neurology.org/content/5/1/e304.full.html

References

This article cites 31 articles, 1 of which you can access for free at: http://ng.neurology.org/content/5/1/e304.full.html\#\#ref-list-1

Subspecialty Collections

This article, along with others on similar topics, appears in the following collection(s):

Multiple sclerosis

http://ng.neurology.org//cgi/collection/multiple_sclerosis

Permissions \& Licensing its entirety can be found online at:

http://ng.neurology.org/misc/about.xhtml\#permissions

Reprints

Information about ordering reprints can be found online: http://ng.neurology.org/misc/addir.xhtml\#reprintsus
\end{abstract}

Information about reproducing this article in parts (figures,tables) or in

Neurol Genet is an official journal of the American Academy of Neurology. Published since April 2015, it is an open-access, online-only, continuous publication journal. Copyright Copyright @ 2019 The Author(s). Published by Wolters Kluwer Health, Inc. on behalf of the American Academy of Neurology.. All rights reserved. Online ISSN: 2376-7839.

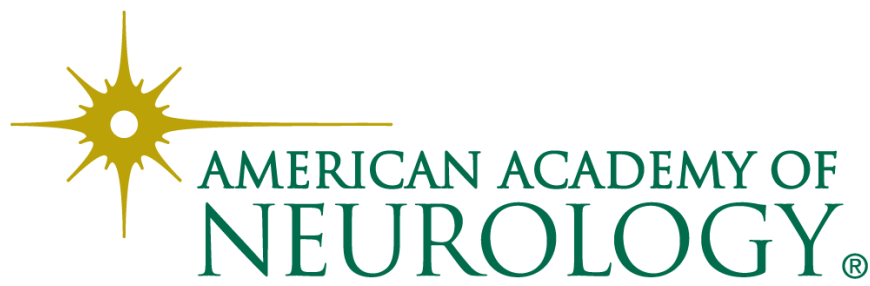

